\title{
FISHERY SURVEY AND RELATED LIMNOLOGICAL CONDITIONS OF WILLIAMS LAKE, HUBBARD COUNTY, MINNESOTA
}

By William W. Taylor, James W. LaBaugh, Mark H. Freeberg and David C. Dowling U.S. GEOLOGICAL SURVEY

Water-Resources Investigations Report 844145

Lakewood, Colorado 1985 


\section{UNITED STATES DEPARTMENT OF THE INTERIOR \\ DONALD PAUL HODEL, Secretary}

GEOLOGICAL SURVEY

Dallas L. Peck, Director

For additional information write to:

James W. LaBaugh U.S. Geological Survey, Box 25046, MS 413 Denver Federal Center Lakewood, CO 80225
Copies of this report can be purchased from:

Open-File Services Section Western Distribution Branch U.S. Geological Survey, MS 306 Box 25425, Federal Center Denver, CO 80225

Telephone: (303) 236-7476 


\section{CONTENTS}

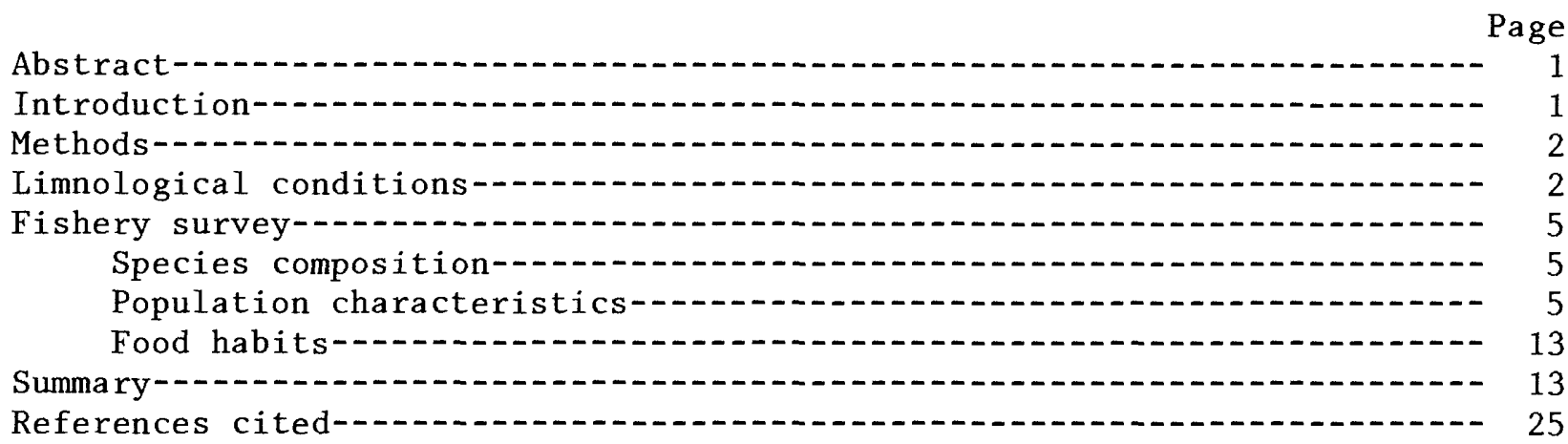

ILLUSTRATIONS

Figure 1. Graphs showing vertical distribution of selected

Page limnological characteristics, August 27, 1982

2. Map showing the extent of the distribution of emergent, floating-leaved, and submerged aquatic macrophytes, July-August 1982-_..... 6

3. Map showing relative distribution of benthic invertebrates in the littoral zone, 1980-82

4-10. Graphs showing population characteristics of fish collected in August 1982. A. Relative abundance by length.

$B$. Relative abundance by age. C. Relation of length to weight:

4. Bluegill-10

5. Pumpkinseed sunfish-_._._._. 12

6. Largemouth bass-_....... 15

7. Northern pike-17

8. Yellow perch-_... 19

9. Rock bass-_... 21

10. Black crappie-n 23 


\section{TABLES}

Table 1. Composition of the zooplankton community, August 27, 1982---.-- 4

2. Taxa of benthic invertebrates in the littoral zone, 1980-82---- 7

3. Species of fish captured, August 31-September 2, 1982-......- 9

4-10. Mean back-calculated lengths for fish collected in

August 1982:

4. Bluegil1-10 9

5. Pumpkinseed-_._. 11

6. Largemouth bass-_... 14

7. Northern pike-10 16

8. Yellow perch-18

9. Rock bass-_. 20

10. Black crappie-12

11. Stomach analysis of fish collected,

August 31-September 2, 1982-1 24

\section{CONVERSION FACTORS}

For the convenience of those readers who prefer to use inch-pound units rather than the International System of Units (SI), the conversion factors for units used in this report are listed below:

Multiply SI unit

centimeter $(\mathrm{cm})$

meter $(\mathrm{m})$

siemens (S)
$B y$

0.393

3.281

1.000
To obtain inch pound unit

inch

feet

mhos 


\title{
FISHERY SURVEY AND RELATED LIMNOLOGICAL CONDITIONS OF WILLIAMS LAKE, HUBBARD COUNTY, MINNESOTA
}

By William W. Taylor', James W. LaBaugh², Mark H. Freeberg', and David C. Dowling'

\begin{abstract}
Bluegill (Lepomis macrochirus), pumpkinseed sunfish (Lepomis gibbosus), largemouth bass (Micropterus salmoides), yellow perch (Perca flavescens), rock bass (Amploplites rupestris), black crappie (Pomoxis nigromaculatus), and northern pike (Esox lucius) were found in Williams Lake, Hubbard County, Minnesota, during a fishery survey of the lake in late August 1982. The most abundant fish were the bluegills. These fish live in the large littoral zone of the lake; this zone underlied 55 percent of the surface area of the lake. The most ubiquitous benthic invertebrate in the littoral zone (amphipods) and the most abundant benthic invertebrate (chironomid larvae) were major food items for the bluegill. Other organisms found in the stomach contents of fish collected in this survey were zooplankton, gastropods, Diptera larvae, odonates, terrestrial insects, and other fish. Daphnia were the only zooplankters of a diverse plankton community that were found in stomach contents. The abundance of fish other than bluegill was typical for a system in which northern pike is the major predator.
\end{abstract}

\section{INTRODUCTION}

Williams Lake, a small lake in north-central Minnesota, is one of several natural lakes selected by the U.S. Geological Survey and its cooperators for intensive field research on the interactions of the hydrologic cycle and nutrient balances of lakes (Siegel and Winter, 1980; LaBaugh and others, 1981). One of the objectives of the ongoing project at this lake is to interrelate the physical and chemical characteristics of the water to biological production. In a preliminary effort to evaluate the fish community in the lake, an exploratory survey of the fish population was conducted in late August 1982. The objectives of this survey were to ascertain species composition, their vital statistics, and their food habits for future reference of the potential impact of fishes in the nutrient cycling and energy flow of this lake. The purpose of this report is to place the findings of the fishery survey in the context of limnological conditions in Williams Lake.

\footnotetext{
${ }^{1}$ Department of Fisheries and Wildlife, Michigan State University, East Lansing, Michigan.

${ }^{2}$ U.S. Geological Survey, Denver, Colorado.
} 


\section{METHODS}

Samples for chemical and plankton community analyses were collected by using methods described by LaBaugh and others (1981). Benthic samples were collected along six transects in the near-shore area of the littoral zone of the lake. Samples were collected by pushing a $20-\mathrm{cm}$ diameter plastic coring tube at least $5 \mathrm{~cm}$ into the bottom material. Contents of the tube were held in place with a piston from a Livingstone piston corer. Next, the tube was removed from the bottom sediments. Then, the contents were emptied into plastic containers and formalin was added to preserve the sample for subsequent analysis. The distance from shore at which the zone of emergent, floating-leaved, and submerged aquatic macrophytes ended was measured along the same transects along which benthic samples were collected. In between transects, the limit of occurrence for submerged macrophytes was inferred from the depth contour map of the lake. Benthic samples were collected in July 1980 , October 1981, and July 1982. The survey of the aquatic macrophytes in Williams Lake occurred in July-August 1982.

Collection of fish began on August 31, 1982, and continued through September 2, 1982, using fyke nets and gill nets in accordance with provisions in a permit issued by the Minnesota Department of Natural Resources. Electrofishing techniques were tried but were ineffectual due to the abundance of aquatic vegetation in the littoral zone. Four $2.54-\mathrm{cm}$ stretch-mesh fyke nets with a 15.2-m lead were used during the 48-hour survey. Net placement was planned after a preliminary examination of the physical characteristics of the littoral zone of the lake. The basic procedure was to choose a site randomly for net placement in each observably different habitat type--vegetated, rocky, or sandy. In addition, an attempt was made to collect fish in shallow $(<1.5-\mathrm{m}$ depth) and deep water. Samples from the fyke nets were collected after 12 hours at each sampling site; the cumulative collection time was 96 hours.

Two experimental gill nets were used in the littoral and limnetic regions of Williams Lake. The nets were $150 \mathrm{ft}$ in length and were composed of six 25-ft panels. The mesh sizes of the stretch-mesh panels were: $2.54 \mathrm{~cm}$, $3.81 \mathrm{~cm}, 5.08 \mathrm{~cm}, 6.36 \mathrm{~cm}, 7.62 \mathrm{~cm}$, and $10.16 \mathrm{~cm}$. Captured fish were identified to species and measured for length and weight. Additionally, several body scales were removed from selected fish for age-growth analysis. The fish were then released, live, to Williams Lake.

A preliminary analysis of stomach contents was performed on one to four fish of each captured species, except northern pike. The number of fish sacrificed was limited by the provisions of the collecting permit issued by the Minnesota Department of Natural Resources.

\section{LIMNOLOGICAL CONDITIONS}

A summary of the vertical distribution of temperature, specific conductance, $\mathrm{pH}$, and dissolved oxygen, measured on August 27, 1982, is shown in figure 1. The lake was thermally stratified. An inverse clinograde vertical distribution was measured for specific conductance. A clinograde vertical distribution was measured for dissolved oxygen and $\mathrm{pH}$. These conditions in 

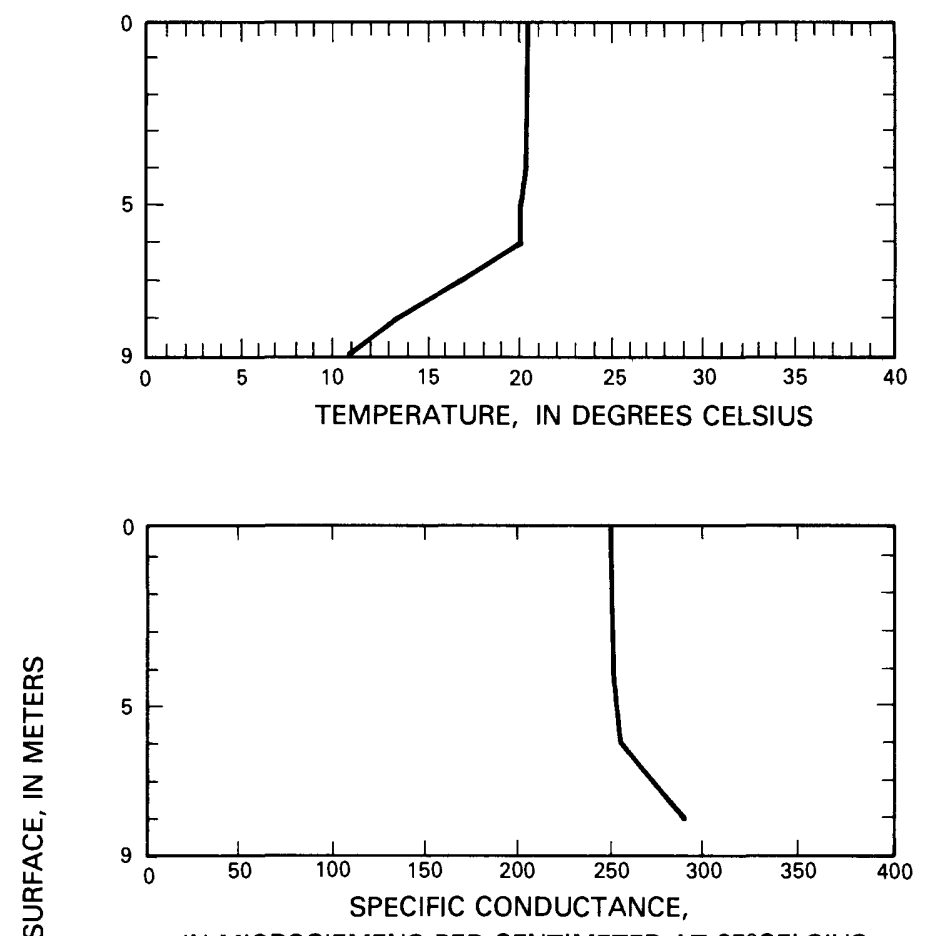

IN MICROSIEMENS PER CENTIMETER AT $25^{\circ} \mathrm{CELSIUS}$

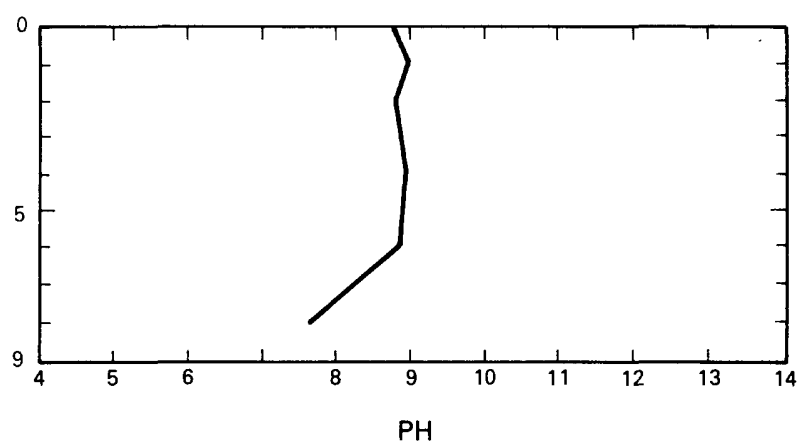

PERCENT SATURATION OF DISSOLVED OXYGEN

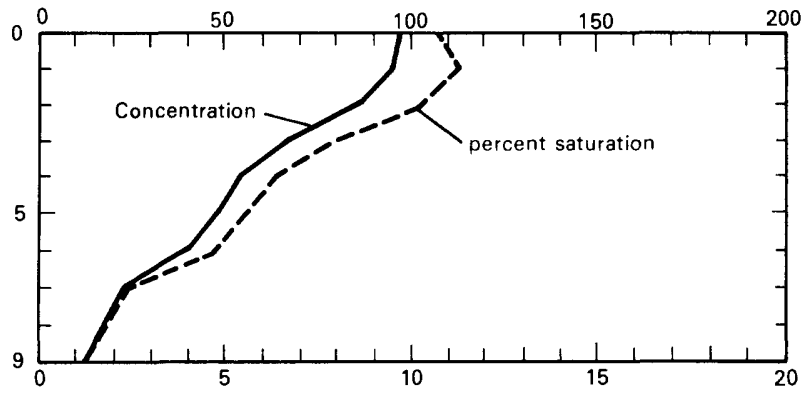

DISSOLVED-OXYGEN CONCENTRATION, IN MILLIGRAMS PER LITER

Figure 1.--Vertical distribution of selected limnological characteristics, August 27, 1982. 
the water column were similar to those reported for August 1979 by LaBaugh and others (1981) and for the same time in 1980 and 1981 (based on unpublished data). The Secchi-disk transparency of $4.8 \mathrm{~m}$ measured on August 27, 1982, also was typical for late August.

LaBaugh and others (1981) indicated blue-green algae and copepods were the dominant groups of the planktonic community of Williams Lake, when it was thermally stratified in the summer of 1979. At the time of the fish population survey reported here, blue-green algae again were the numerically dominant group among the phytoplankton. However, the most abundant zooplankton group was the rotifers (table 1). Daphnia galeata mendotae was the only species of Daphnia present in the zooplankton community. Daphnia were the only zooplankters found in the stomach contents of fish collected during this investigation.

Table 1.--Composition of the zooplankton community, August 27, 1982

\begin{tabular}{|c|c|c|c|}
\hline \multirow[b]{2}{*}{ Taxa } & \multicolumn{3}{|c|}{ Number of organisms per liter } \\
\hline & Replicate & $1 \quad$ Replicate & 2 \\
\hline Copepoda-- & 50.1 & 50.6 & \\
\hline Orthocyclops modestus & ---- & 1.8 & \\
\hline Cyclops biscuspidatus thomasi-n & 1.4 & 2.8 & \\
\hline Cyclopoid copepodids & 11.6 & 9.3 & \\
\hline Diaptomus oregonensis & --- & 1.0 & \\
\hline Calanoid copepodids & 7.0 & 3.1 & \\
\hline Copepod naupli & 30.1 & 32.6 & \\
\hline Cladocera-c- & 60.3 & 61.5 & \\
\hline Diaphanosoma leuctenbergianum-............. & 7.4 & 8.0 & \\
\hline Daphnia galeata mendotae-1. & 6.5 & 8.5 & \\
\hline Ceriodaphnia lacustris- & .5 & ---- & \\
\hline Bosmina longirostris & .5 & 1.0 & \\
\hline Chydorus spaericus-nen & 45.4 & 44.0 & \\
\hline Rotifera-n- & 55.6 & 95.1 & \\
\hline Conochilus unicornis- & 19.9 & 45.8 & \\
\hline Polyarthra dolichoptera- & .5 & $\ldots$ & \\
\hline Polyarthra vulgaris- & --- & 1.0 & \\
\hline Gastropus hyptopus & .9 & 1.0 & \\
\hline Asplanchna priodonta group & .5 & 1.3 & \\
\hline Kellicottia Iongispina- & 4.6 & 4.4 & \\
\hline Keratella cochlearis & 26.4 & 36.2 & \\
\hline Monostyla sp. & 1.4 & 4.4 & \\
\hline Trichocerca sp- & 1.4 & 1.0 & \\
\hline
\end{tabular}


In July and August of 1982, a preliminary survey was made of the distribution of aquatic macrophytes in Williams Lake; results of that survey are shown in figure 2. The area of the lake surface containing or underlain by aquatic macrophytes was 55 percent of the total surface area. Submersed macrophytes were found throughout the littoral zone. Floating-leaved macrophytes were absent from most of the northeast side of the lake. Sampling of the fish population with fyke nets was designed to avoid any possible bias introduced by the spatial variability of the aquatic-macrophyte community.

The benthic-invertebrate community of the littoral zone was diverse (table 2). The amphipod Hyatella azteca was a ubiquitous member of the benthic community, being found at every sampling transect during the October 1981 collection. Amphipods were the most numerous prey found among the stomach contents of bluegills. Chironomids usually were the most abundant organisms at each sampling transect (fig. 3). Chironomids were also prey of bluegills.

\section{FISHERY SURVEY}

\section{Species Composition}

Seven species were captured during this fishery investigation. The predominant species in Williams Lake is the bluegill (Lepomis macrochirus), which lives in the vegetation along the shore line (table 3 ). The pumpkinseed sunfish (Lepomis gibbosus) and largemouth bass (Micropterus salmoides) would be considered common, with northern pike (Esox lucius) present in average abundance for a top carnivore. Yellow perch (Perca flavescens), rock bass (Amploplites rupestris), and black crappie (Pomoxis nigromaculatus) were captured infrequently.

\section{Population Characteristics}

The majority of bluegills collected were between 12 and $16 \mathrm{~cm}$ in total length (fig. 4A). These fish primarily were age 4 and 5 years (fig. 4B). These fish were smaller than expected for a normal population (Carlander, 1977) indicating that an overabundance of bluegill occurs, which inhibits their growth (table 4).

The length of fish in any year of life prior to collection of a scale for growth analysis is shown for bluegill from Williams Lake in table 4 . The method of comparing scale size (radius) to fish size (length) at a known age, and then determining what length the fish must have been at an earlier age, is known as back calculation. For example, bluegill sampled in this study whose scale annuli indicated they were 3 years old or older, but less than 4 years old, had a mean length of $10.7 \mathrm{~cm}$. Fish in this age group were not all exactly 3 years old, so the length of fish at age 3 will be some value less than 10.7; some growth will have occurred in those fish older than 3 years in age. By comparing scale growth to fish length, the average length of bluegill fish at 3 years of age was calculated to be $10.4 \mathrm{~cm}$. When these 3 -year old fish were 1 year old, their average length was calculated to be $7.3 \mathrm{~cm}$. These data are used to interpret the growth characteristics of the fish population in the lake. 

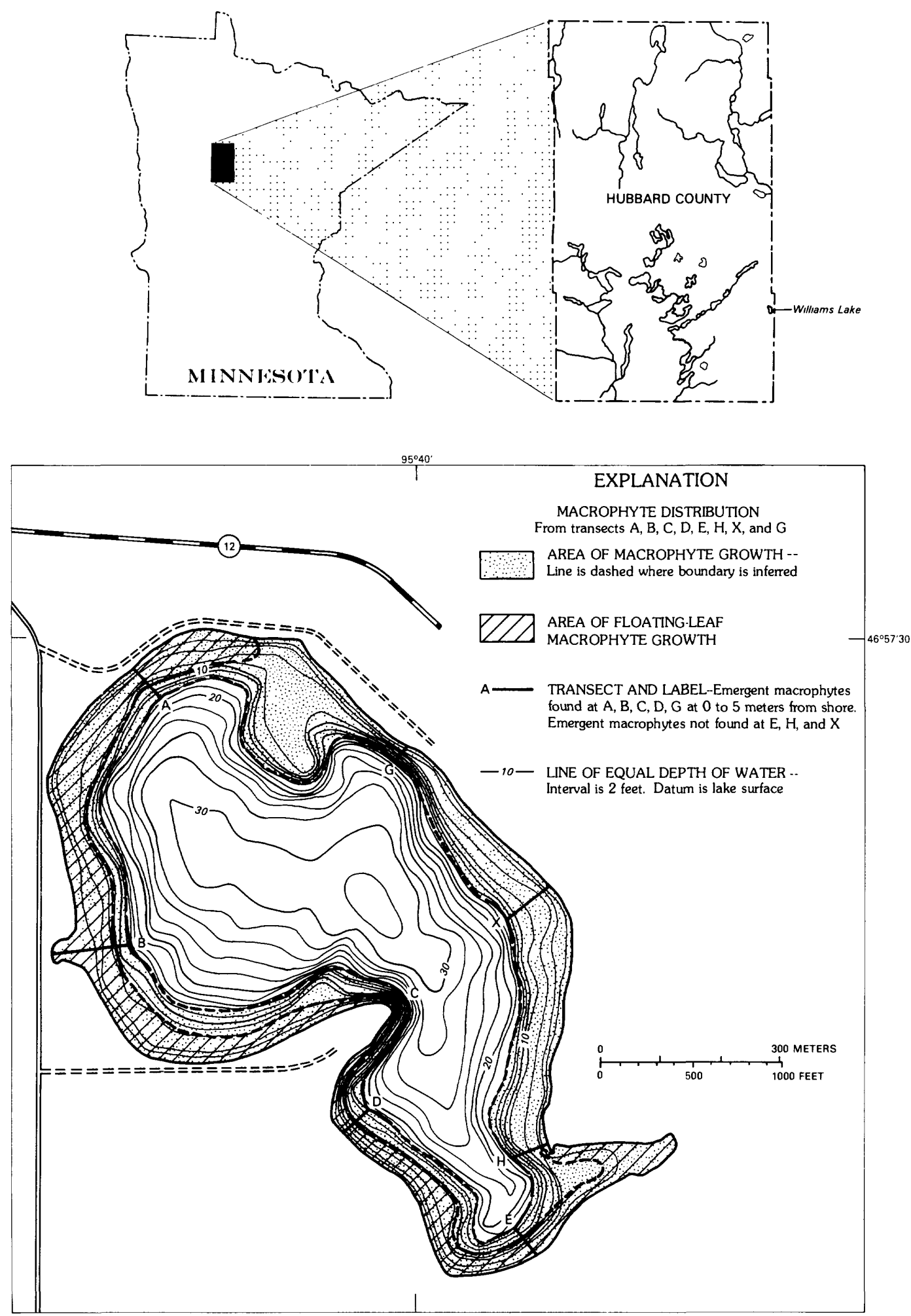

Figure 2.--Extent of the distribution of emergent, floating-leaved, and submerged aquatic macrophytes, July-August 1982. 
Table 2.--Taxa of benthic invertebrates in the littoral zone, 1980-82.

Diptera

Chironomidae

Cladotanytarsus

Psectrocladius

stichtochiromomus

Larsia

Polypedilum

Ceraptogonidae

Bezzia, Probezzia

Palpomyia

$\begin{array}{lcr}\text { Trissocladium } & \text { Cryptochiromus } & \text { Zaurilimyia } \\ \text { Trichocladius } & \text { Tanytarsus } & \text { Labrundinea } \\ \text { Diamesa } & \text { Procladius } & \text { Dicrotendipes } \\ \text { Paratanytarsus } & \text { Lauterborniella } & \text { Pseudochironomus } \\ \text { Phaenospectra } & \text { Microtendipes } & \text { Psectrotanypus } \\ & \text { Tabanidae } & \\ \text { Stilobezzia } & \text { Chrysops } \\ \text { Culicoides } & & \end{array}$

Trichoptera

Molanna

Phryganea

oxythria

oecetis

Ceraclea

Ephemeroptera

Choroterpes

Paracloedes

Caenis

Gomphus

Odonata

Hexagenia

Ephemerella

Mystacides

Amphipoda

Hyatella azteca

Gastropoda
Amnicola
Gyraulus
Physa
Pelecypoda

Limnodrilus

Pisidium
Oligocheata

Chaetogaster Iimnaei

specaris josinae

Pristina

Peloscolex

Tubificidae

Nais communis

Dero digitata

Amphicheata americanus

Lumbriculidae
Spaherium

stylarsia

fossularis

Coleoptera

Donacia

Halipus
Enall agma

Libellula

\section{Stylaria lacustris}

stylodrilus heringianus

Chaetogaster cristallinus

Lumbriculus variagatus

Homochaeta

Dero nivca

Aulodrilus

Uncinais uncinata
Nematomorpha

Gordius

Nematoda

Bactrachobdella

Eudorylaimus

Tylenchus

Aphanolaimus
Polychaeta

Manyonkia speciosa

Hi rudinea

Hydracarina

Anonchus 


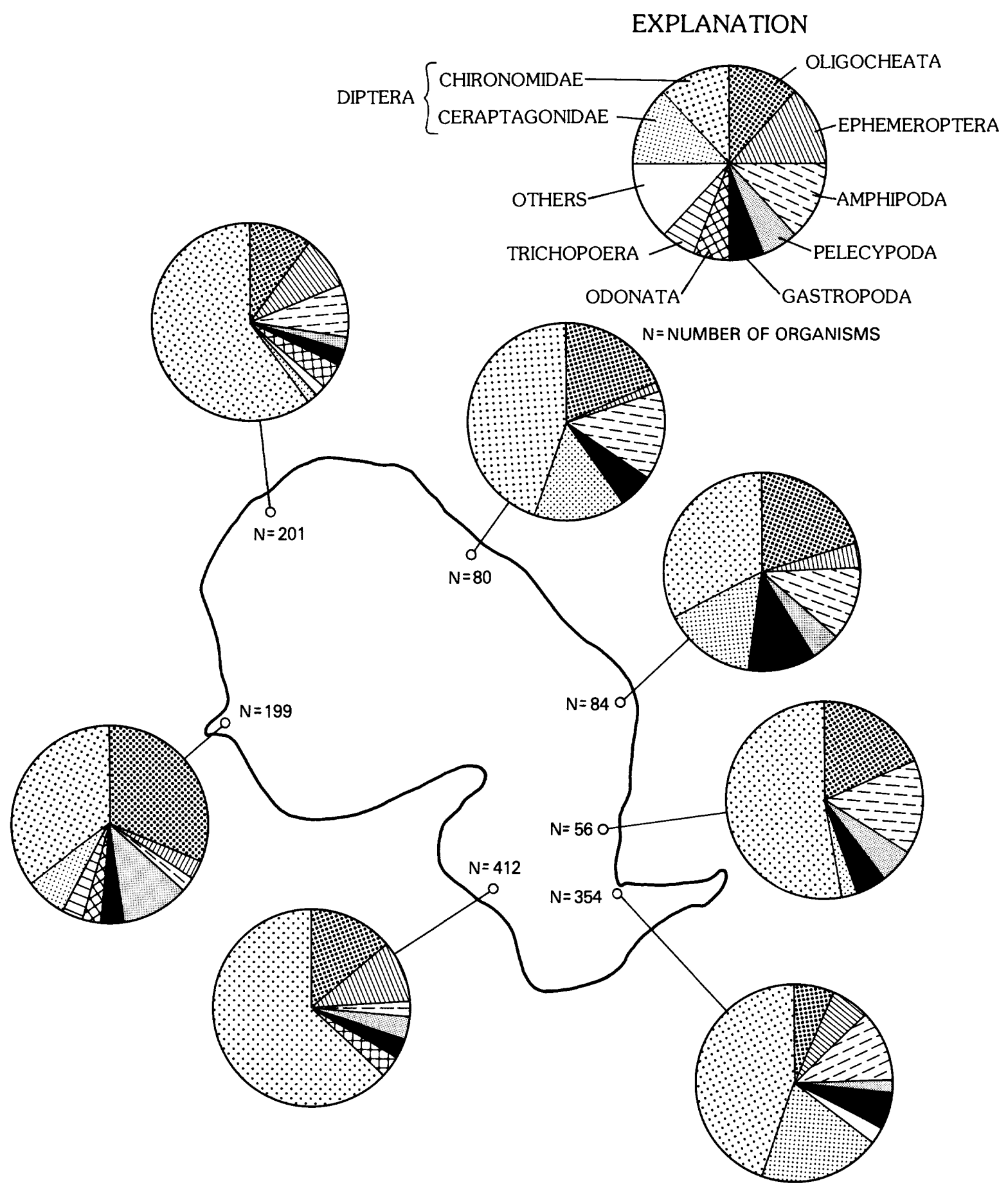

Figure 3.--Relative distribution of benthic invertebrates in the littoral zone, 1980-82. 


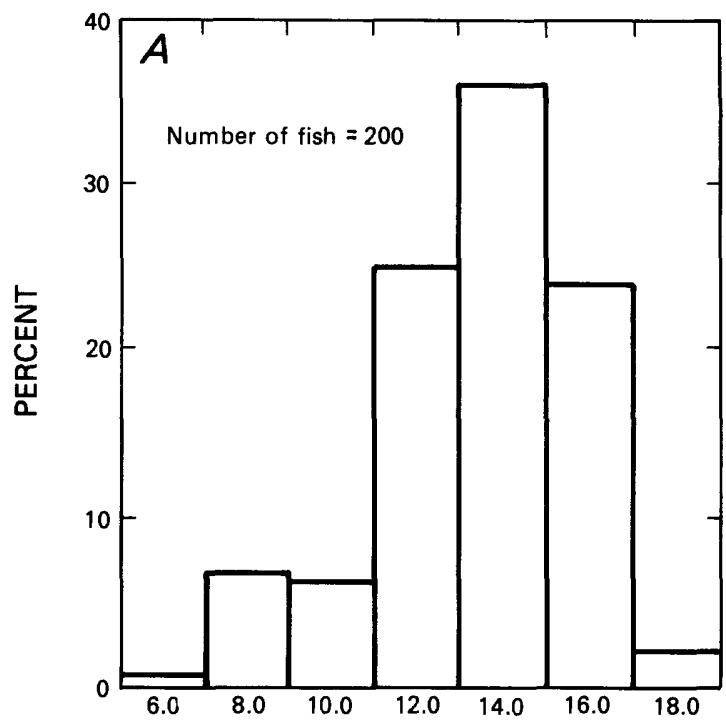

LENGTH AT MIDDLE OF INTERVAL. IN CENTIMETERS

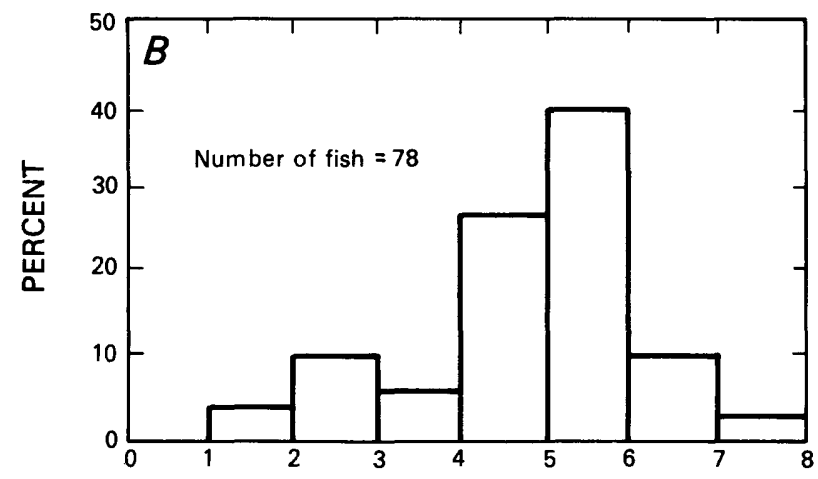

AGE, IN YEARS

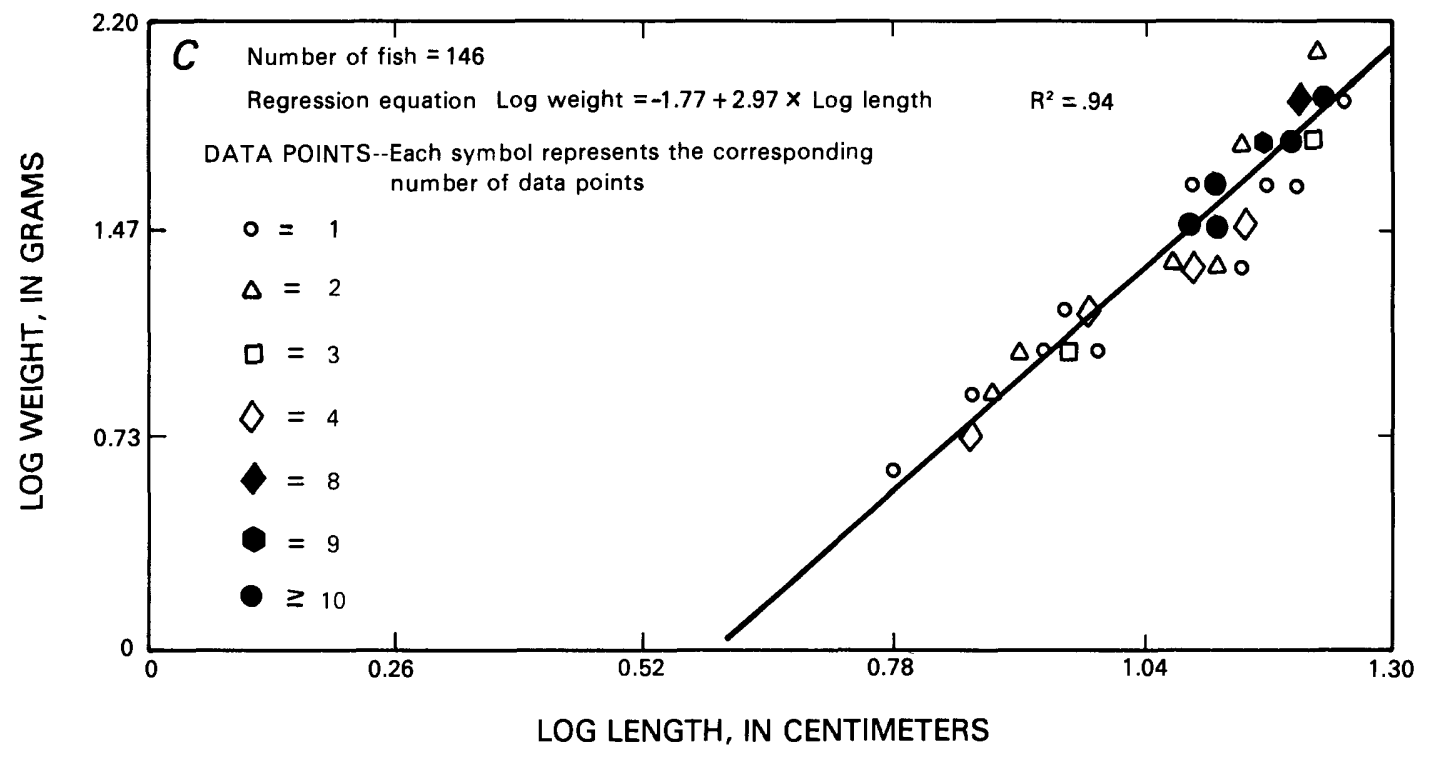

Figure 4.--Population characteristics of bluegill collected in August 1982. A. Relative abundance by length.

$B$. Relative abundance by age. C. Relation of length to weight. 
Growth characteristics of fish populations also can be examined by use of the relation between weight and length. The weight-length relationship can be expressed as :

$$
W=a L^{b}
$$

where

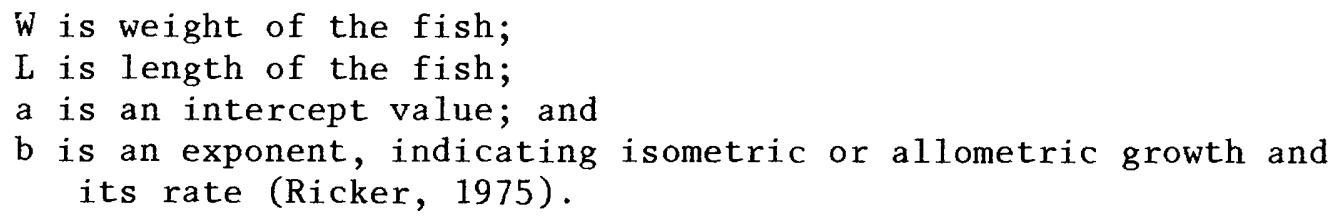

Generally, a " $b$ " value of 3 indicates a fish is growing isometrically; body proportions are unchanged with growth (Bagenal, 1978). A value greater or less than 3 indicates allometric growth; that is, the fish becomes heavier or lighter for its length as it grows longer and body proportions change with growth. Bluegills in Williams Lake are growing nearly isometrically as indicated by a "b" value of 2.97 ( $\mathrm{fig}$. 4C), which is slower than a normally growing population (Carlander, 1977).

Forty-three percent of the pumpkinseed sunfish collected were $16 \mathrm{~cm}$ in total length (fig. 5A). These fish primarily were 3 years old (fig. 5B). Growth was slightly greater than average compared with those reported by other investigators (Carlander, 1977)(table 5, fig. 5C).

Table 5.--Mean back-calculated lengths for pumpkinseed sunfish collected in August 1982

$[\mathrm{cm}$, centimeters ]

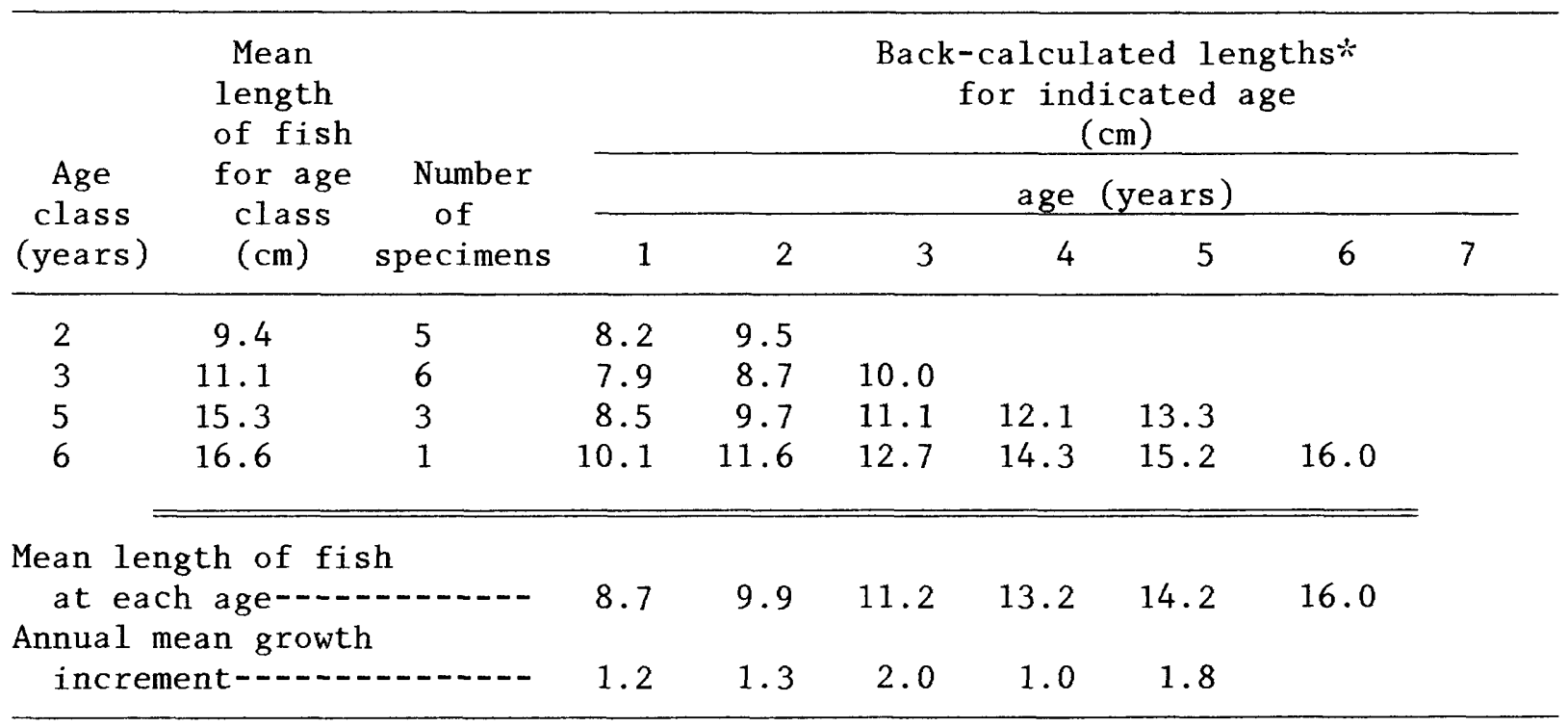

*Calculated average length of $\mathrm{fish}$ for each age class at a specific age in their life history. 


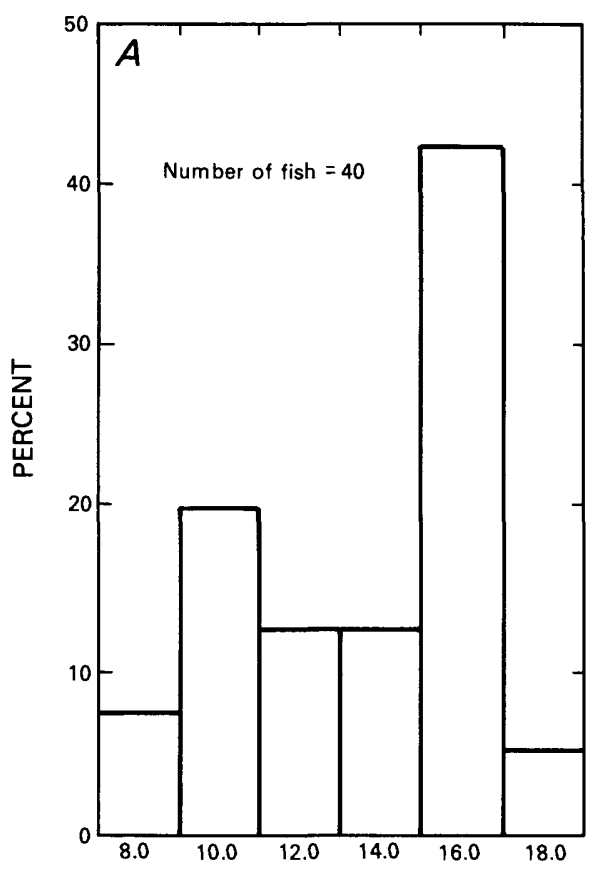

LENGTH AT MIDDLE OF INTERVAL, IN CENTIMETERS

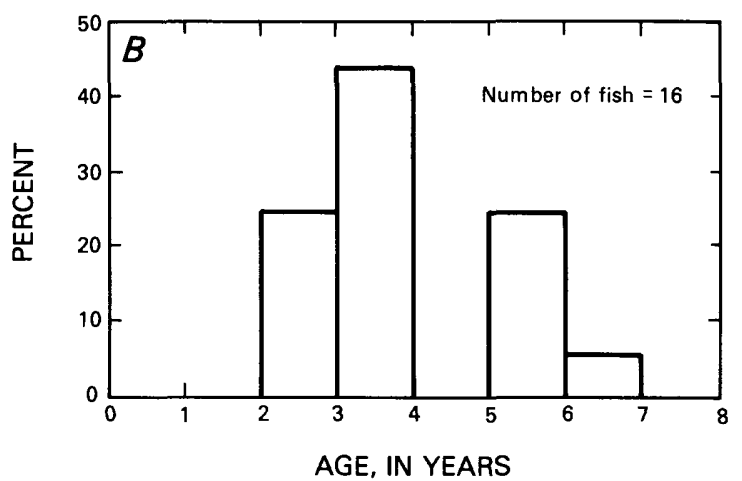

AGE, IN YEARS

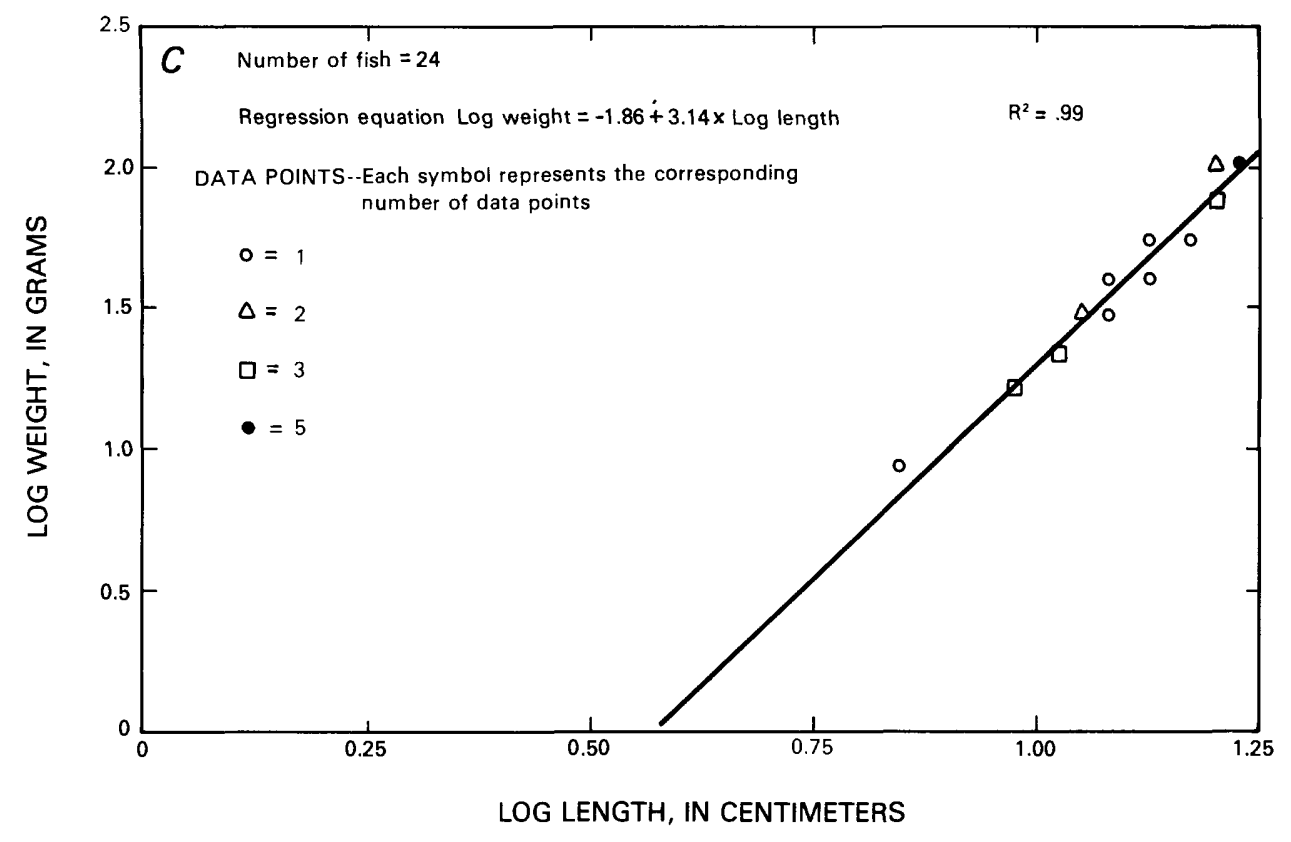

Figure 5.--Population characteristics of pumpkinseed sunfish collected in August 1982. A. Relative abundance by length. $B$. Relative abundance by age. C. Relation of length to weight. 
The largemouth bass population had two dominant size classes, one at $14 \mathrm{~cm}$ and one at $26 \mathrm{~cm}$ (fig. 6A). Overal1, 4-year-old bass predominated, comprising 32 percent of the catch (fig. 6B). The length-weight and growth relationship appeared to be average for this species (Carlander, 1977) (table 6, fig. 6C).

Northern pike collected in the survey ranged between 38 and $78 \mathrm{~cm}$ in length (fig. 7A). Because only $10 \mathrm{fish}$ were captured, our analysis of their vital statistics is incomplete. However, data for the age, length, weight, and growth relationships are given in table 7 and figure $7 B, C$. Caution needs to be used in the interpretation and extrapolation of these data in relation to the total population because of the small sample size. The same is true for yellow perch (table 8, fig. 8A-C), rock bass (table 9, fig. 9A-C), and black crappie (table 10, fig. 10A-C) populations.

\section{Food Habits}

Stomach analyses of selected species are depicted in table 11. Bluegills fed primarily on amphipods during this study; they, in turn, were eaten by largemouth bass, rock bass, and black crappie. Largemouth bass had the greatest diversity in diet, with some fish eating from the water mass (bluegills, Daphnia), and others feeding on the bottom organisms (Amphipods, Chironomid larvae, Diptera larvae, Odonata). Northern pike were not examined for food studies because of their abundance and size.

\section{SUMMARY}

It is clear from this study that the bluegill is a key component in the nutrient and biological energy budget of Williams Lake. Bluegills are abundant (overabundant) living in the very productive littoral zone and feeding on the benthic dwelling invertebrates. These fish, in turn, provide food for the piscivorous fishes, which live in the limnetic and shoreline zone of this lake. Further research, centering on the role of the bluegill in the energy flow and nutrient cycling in Williams Lake, is needed to assess the effect of fish in the functional development of this ecosystem. 
Table 6.--Mean back-calculated lengths for largemouth bass collected in August 1982

[cm, centimeters ]

\begin{tabular}{|c|c|c|c|c|c|c|c|c|c|c|}
\hline \multirow{3}{*}{$\begin{array}{l}\text { Age } \\
\text { class } \\
\text { (years) }\end{array}$} & \multirow{3}{*}{$\begin{array}{l}\text { Mean } \\
\text { length } \\
\text { of fish } \\
\text { for age } \\
\text { class } \\
(\mathrm{cm})\end{array}$} & \multirow{3}{*}{\multicolumn{2}{|c|}{$\begin{array}{l}\text { Number } \\
\text { of } \\
\text { specimens }\end{array}$}} & \multicolumn{7}{|c|}{$\begin{array}{c}\text { Back-calculated lengths* } \\
\text { for indicated age } \\
(\mathrm{cm})\end{array}$} \\
\hline & & & & \multicolumn{7}{|c|}{ age (years) } \\
\hline & & & & 1 & 2 & 3 & 4 & 5 & 6 & 7 \\
\hline 1 & 6.5 & 2 & 5.3 & & & & & & & \\
\hline 2 & 13.6 & 5 & 7.0 & 11.6 & & & & & & \\
\hline 3 & 21.3 & 6 & 7.6 & 13.1 & 18.7 & & & & & \\
\hline 4 & 25.4 & 9 & 6.5 & 11.6 & 16.0 & 21.3 & & & & \\
\hline 5 & 28.6 & 4 & 6.8 & 10.3 & 15.1 & 19.6 & 24.1 & & & \\
\hline 6 & 31.5 & 1 & 6.7 & 10.5 & 13.8 & 19.6 & 22.7 & 27.7 & & \\
\hline 8 & 43.2 & 11 & 5.4 & 11.9 & 17.6 & 23.9 & 30.2 & 34.8 & 39.2 & 42.5 \\
\hline $\begin{array}{l}\text { Mean len } \\
\text { at eac } \\
\text { Annual }\end{array}$ & $\begin{array}{l}\text { gth of } f i \\
\text { h a ge- } \\
\text { ean growtl }\end{array}$ & sh & 6.5 & 11.5 & 16.2 & 21.1 & 25.7 & 31.3 & 39.2 & 42.5 \\
\hline increm & ent--... & --- & 5.0 & 4.7 & 4.9 & 4.6 & 5.6 & 7.9 & 3.3 & \\
\hline
\end{tabular}

*Calculated average length of fish for each age class at a specific age in their life history. 


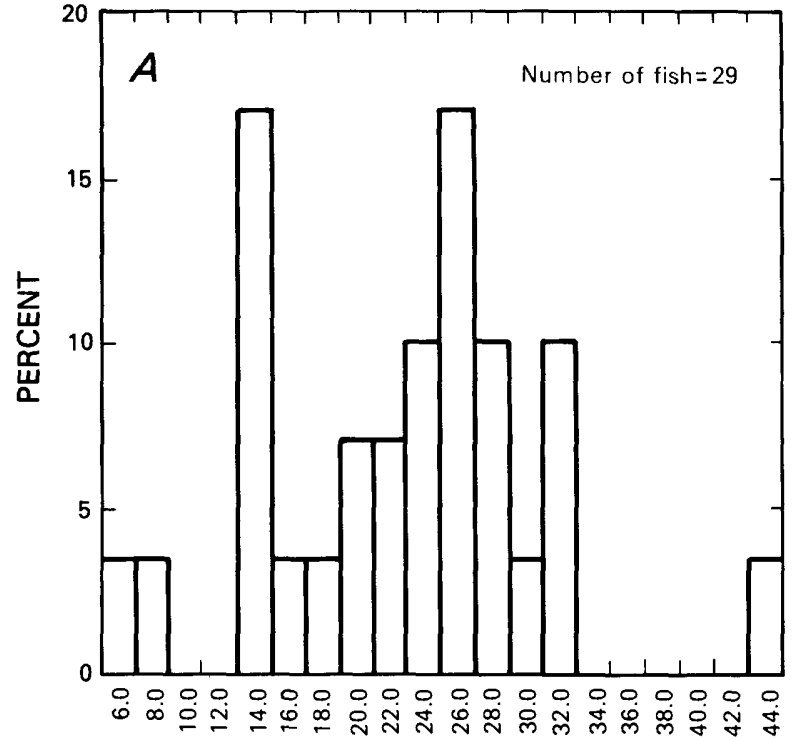

LENGTH AT MIDDLE OF INTERVAL, IN CENTIMETERS

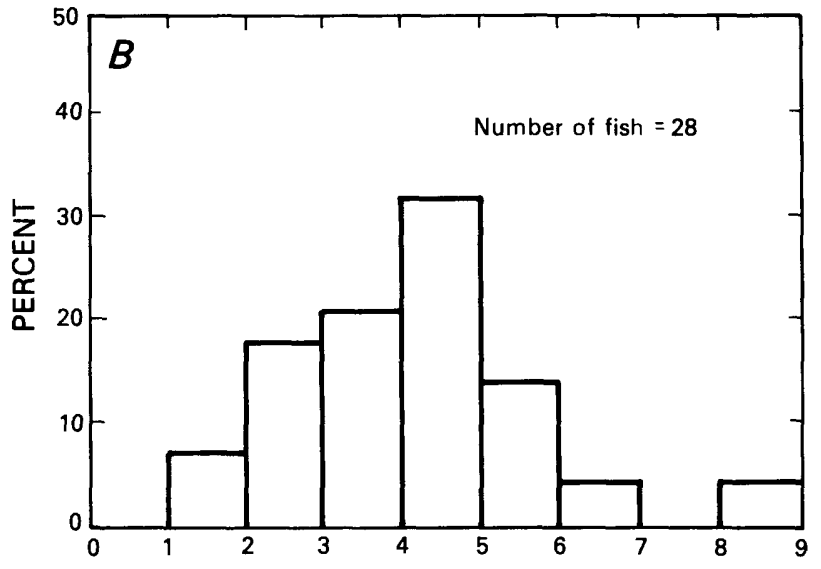

AGE, IN YEARS

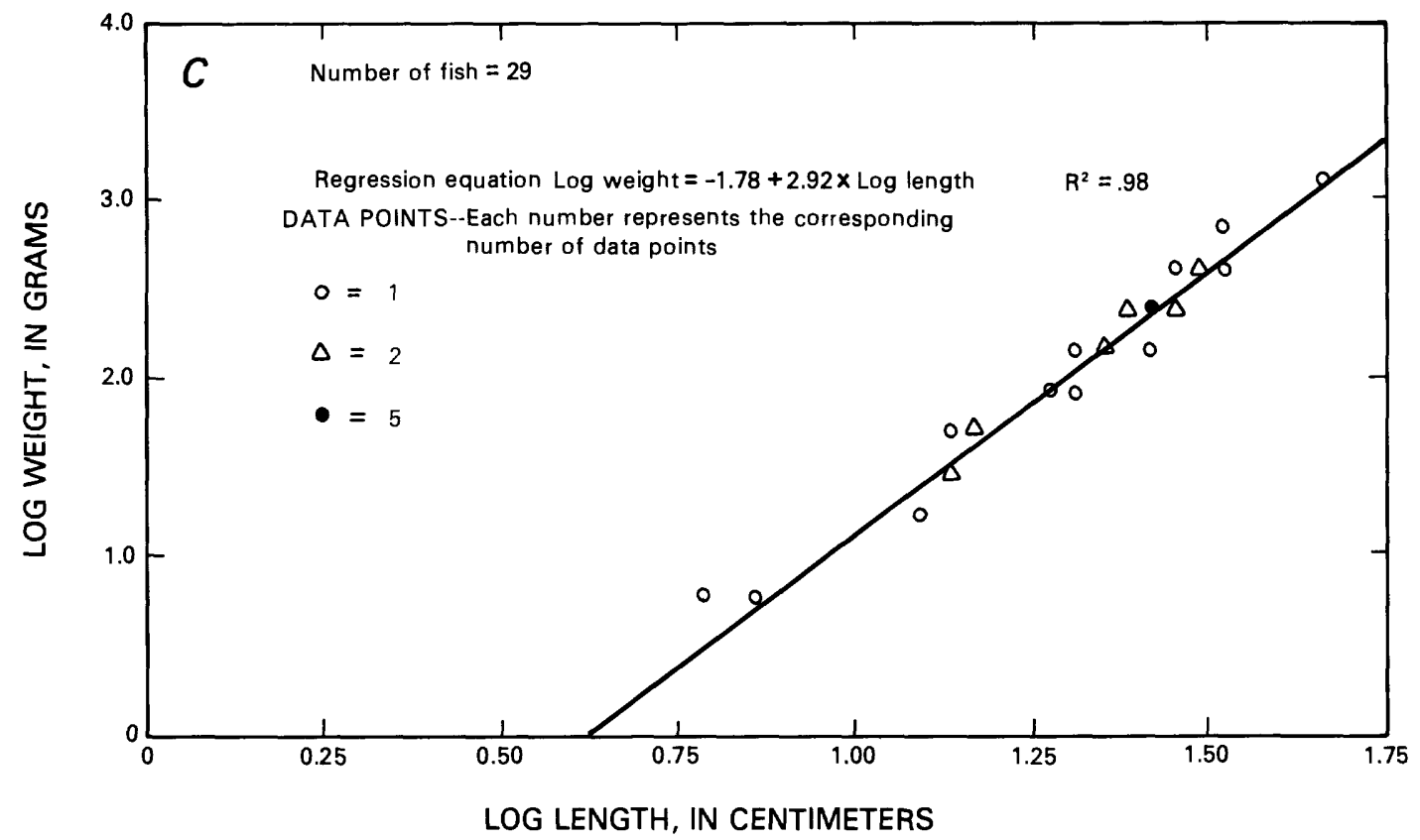

Figure 6.--Population characteristics of largemouth bass collected in August 1982. A. Relative abundance by length. $B$. Relative abundance by age. C. Relation of length to weight. 
Table 7.--Mean back-calculated lengths for northern pike collected in August 1982

[cm, centimeters ]

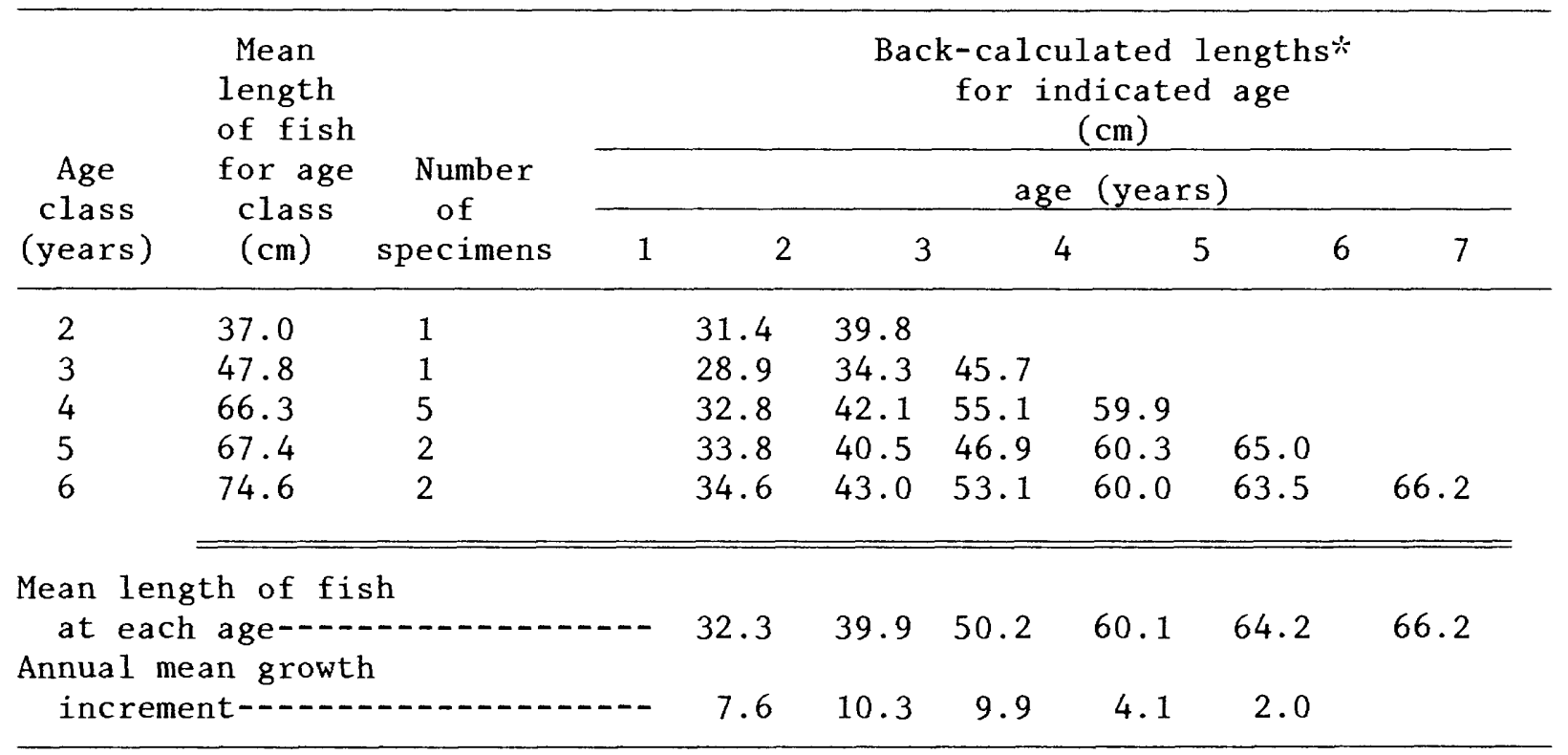

*Calculated average length of fish for each age class at a specific age in their life history. 


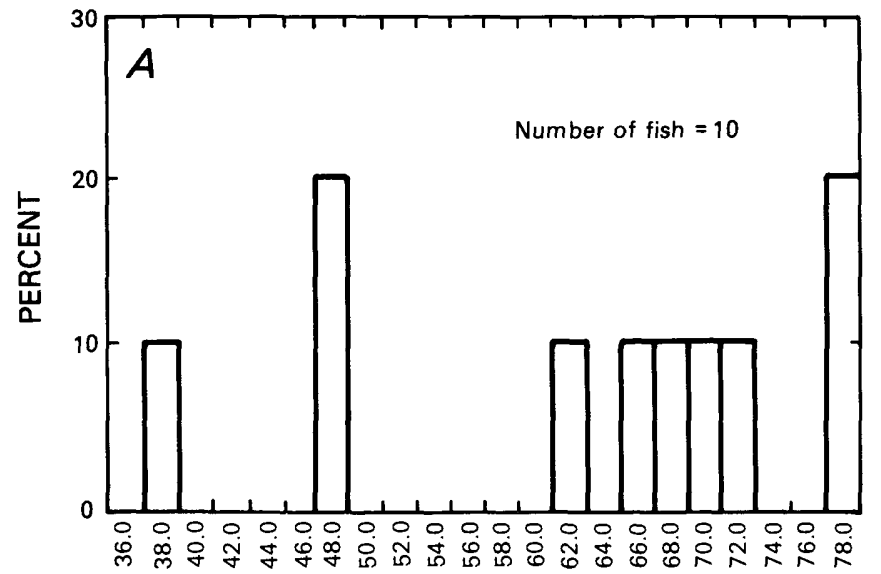

LENGTH AT MIDDLE OF INTERVAL, IN CENTIMETERS

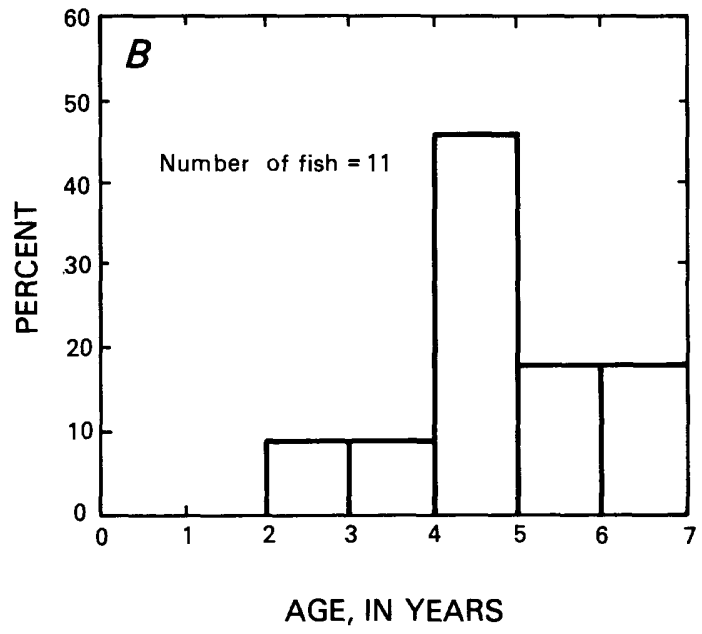

AGE, IN YEARS

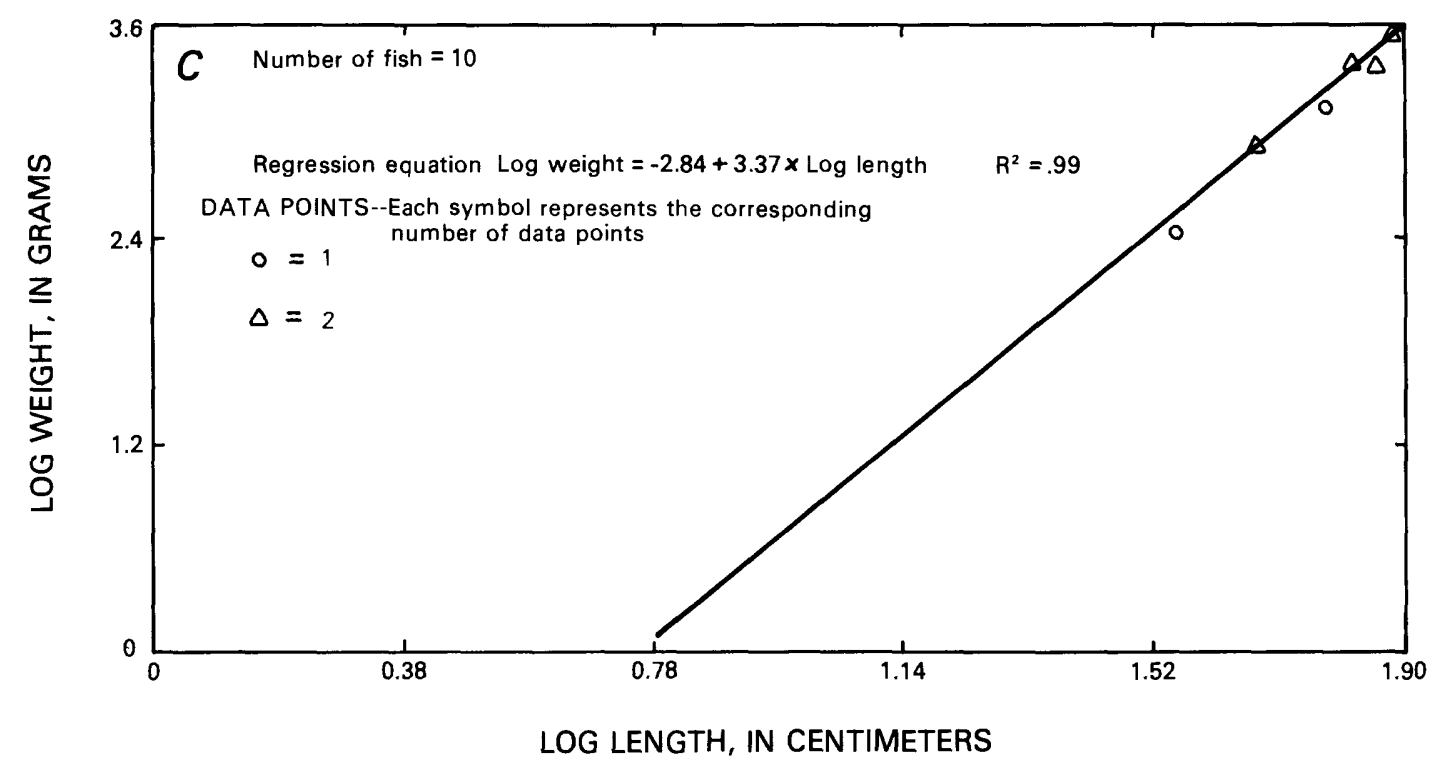

Figure 7.--Population characteristics of northern pike collected in August 1982. A. Relative abundance by length. B. Relative abundance by age. C. Relation of length to weight. 
Table 8.--Mean back-calculated lengths for yellow perch collected in August 1982

[cm, centimeters]

\begin{tabular}{|c|c|c|c|c|c|c|c|c|c|}
\hline \multirow{3}{*}{$\begin{array}{l}\text { Age } \\
\text { class } \\
\text { (years) }\end{array}$} & \multirow{3}{*}{$\begin{array}{l}\text { Mean } \\
\text { length } \\
\text { of fish } \\
\text { for age } \\
\text { class } \\
(\mathrm{cm})\end{array}$} & \multirow{3}{*}{$\begin{array}{l}\text { Number } \\
\text { of } \\
\text { specimens }\end{array}$} & & \multicolumn{6}{|c|}{$\begin{array}{c}\text { Back-calculated lengths* } \\
\text { for indicated age } \\
(\mathrm{cm})\end{array}$} \\
\hline & & & & \multicolumn{6}{|c|}{ age (years) } \\
\hline & & & 1 & 2 & 3 & 4 & 5 & 6 & 7 \\
\hline 3 & 17.0 & 2 & & 15.6 & 16.2 & 17.0 & & & \\
\hline 4 & 19.6 & 6 & & 16.0 & 17.0 & 18.0 & 18.7 & & \\
\hline 5 & 19.9 & 4 & & 16.0 & 17.0 & 17.9 & 18.8 & 19.3 & \\
\hline \multirow{2}{*}{\multicolumn{4}{|c|}{$\begin{array}{l}\text { Mean length of fish } \\
\text { at each age- } \\
\text { Annual mean growth } \\
\text { increment- }\end{array}$}} & 15.9 & 16.8 & 17.6 & 18.8 & 19.3 & \\
\hline & & & & .9 & .8 & 1.2 & .5 & & \\
\hline
\end{tabular}

*Calculated average length of $\mathrm{fish}$ for each age class at a specific age in their life history. 


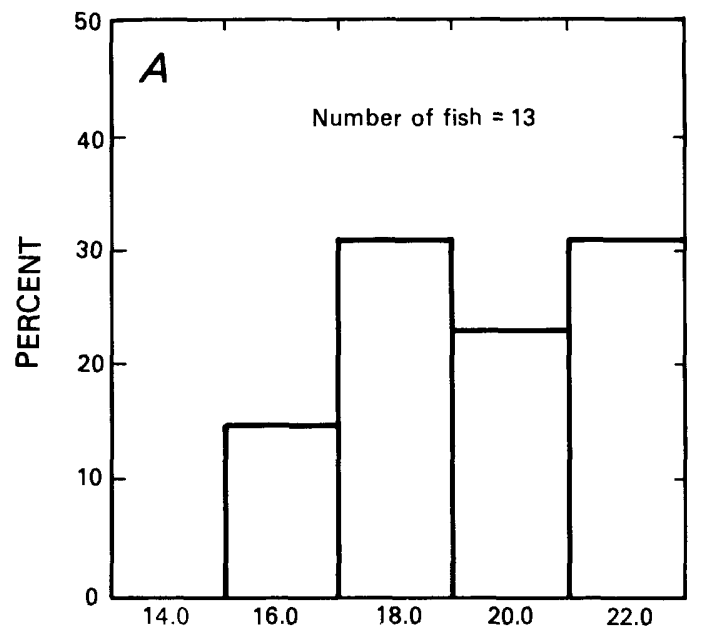

LENGTH AT MIDDLE OF INTERVAL, IN CENTIMETERS

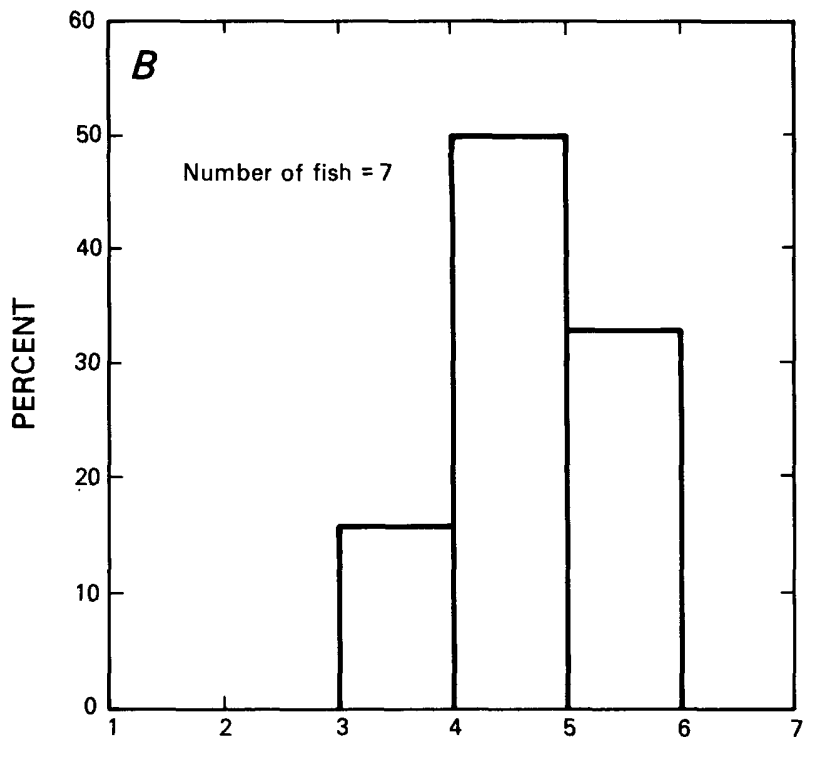

AGE, IN YEARS

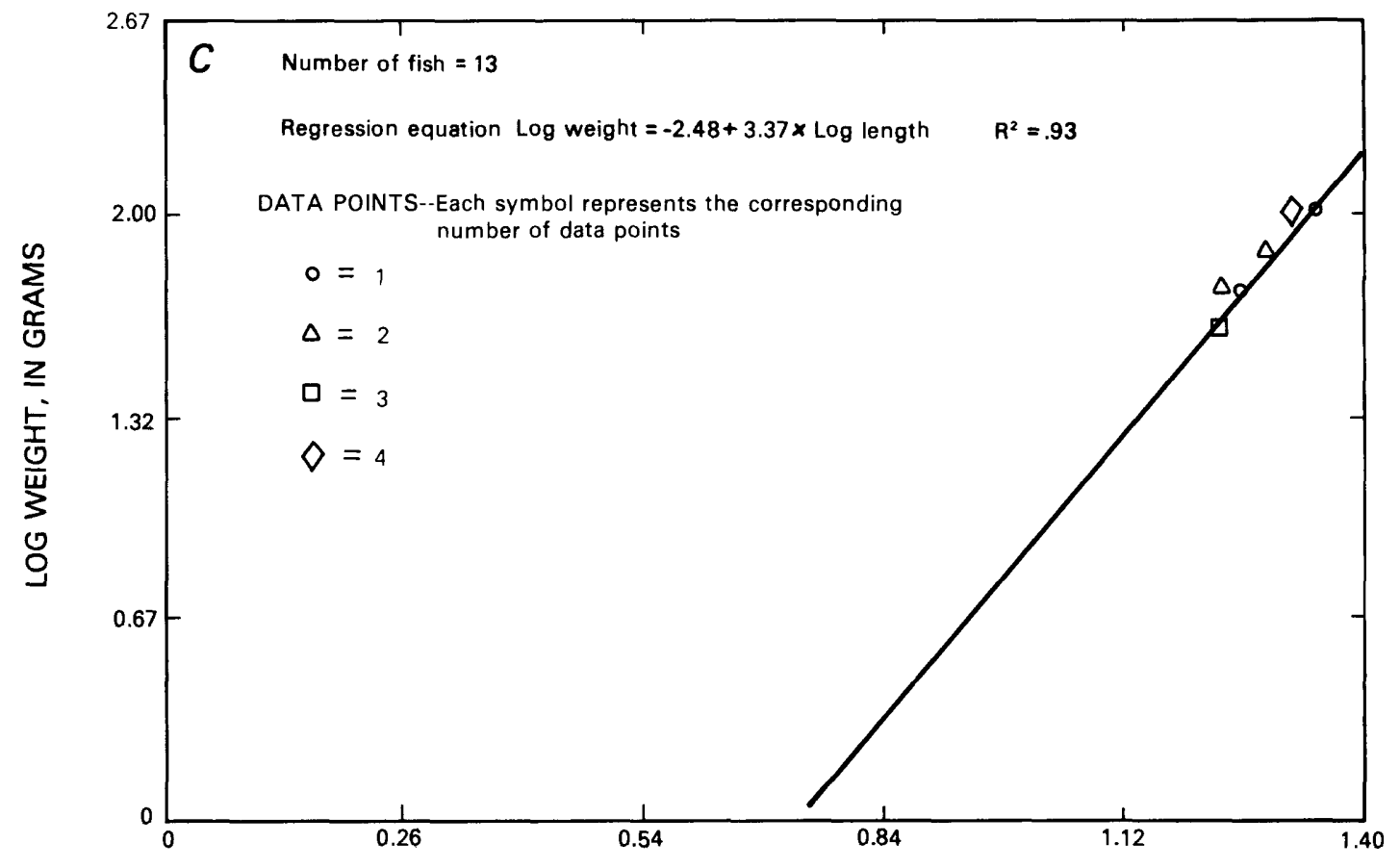

LOG LENGTH, IN CENTIMETERS

Figure 8.--Population characteristics of yellow perch collected in August 1982. A. Relative abundance by length. B. Relative abundance by age. C. Relation of length to weight. 
Table 9.--Mean back-calculated lengths for rock bass collected in August 1982

$[\mathrm{cm}$, centimeters ]

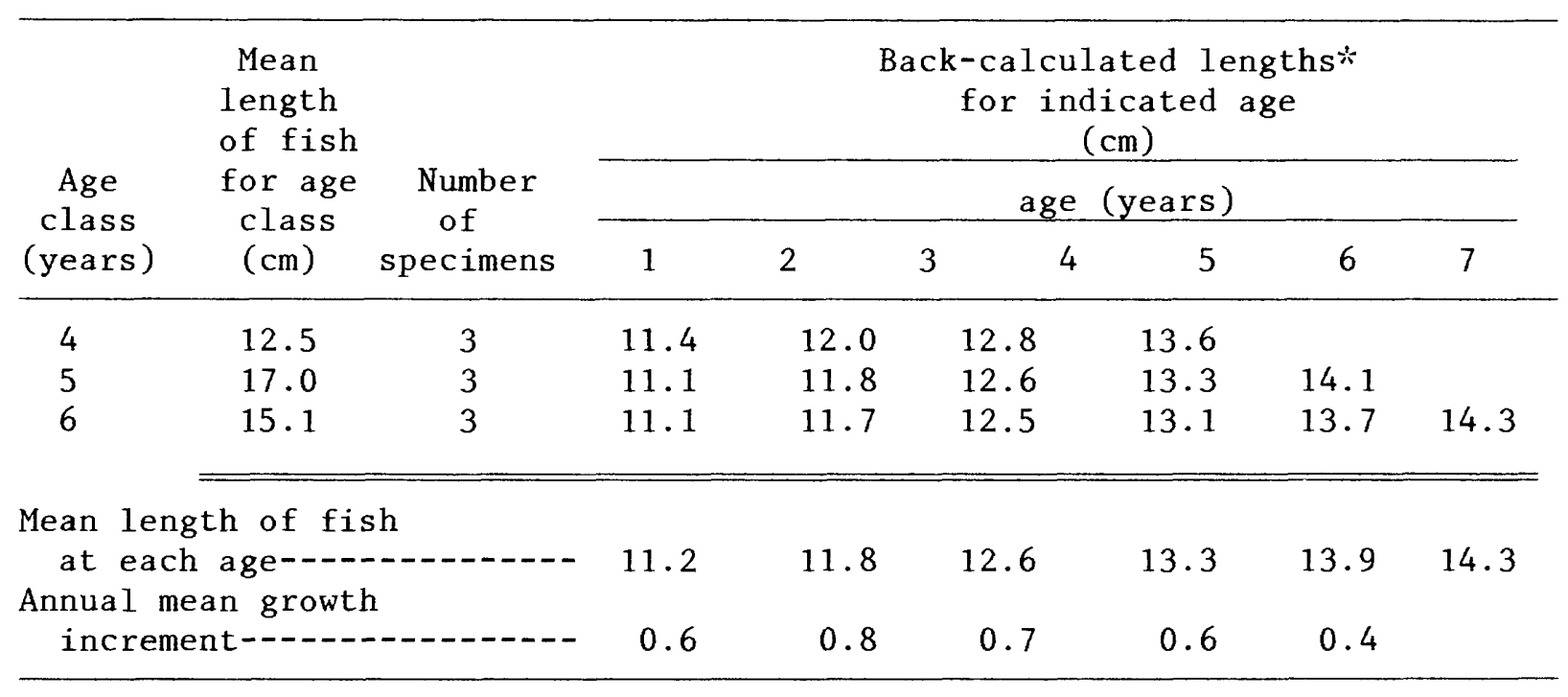

*Calculated average length of fish for each age class at a specific age in their life history. 


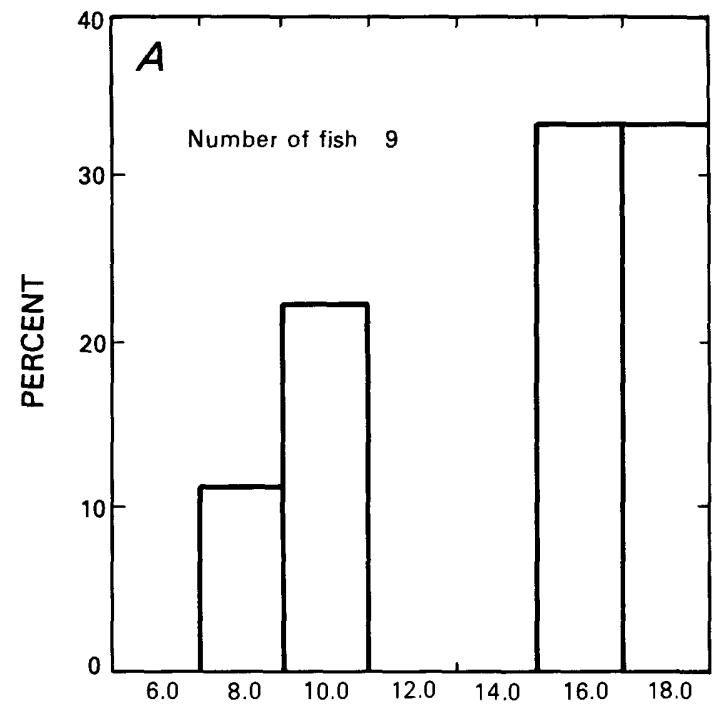

LENGTH AT MIDDLE OF INTERVAL, IN CENTIMETERS

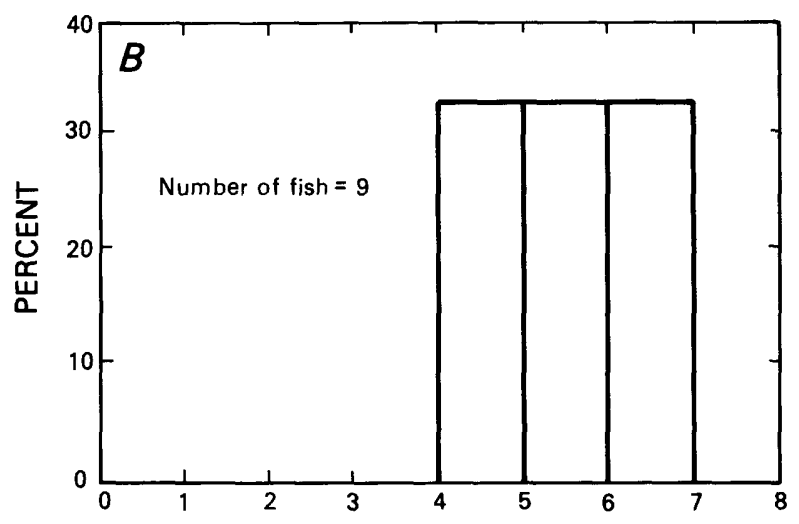

AGE, IN YEARS

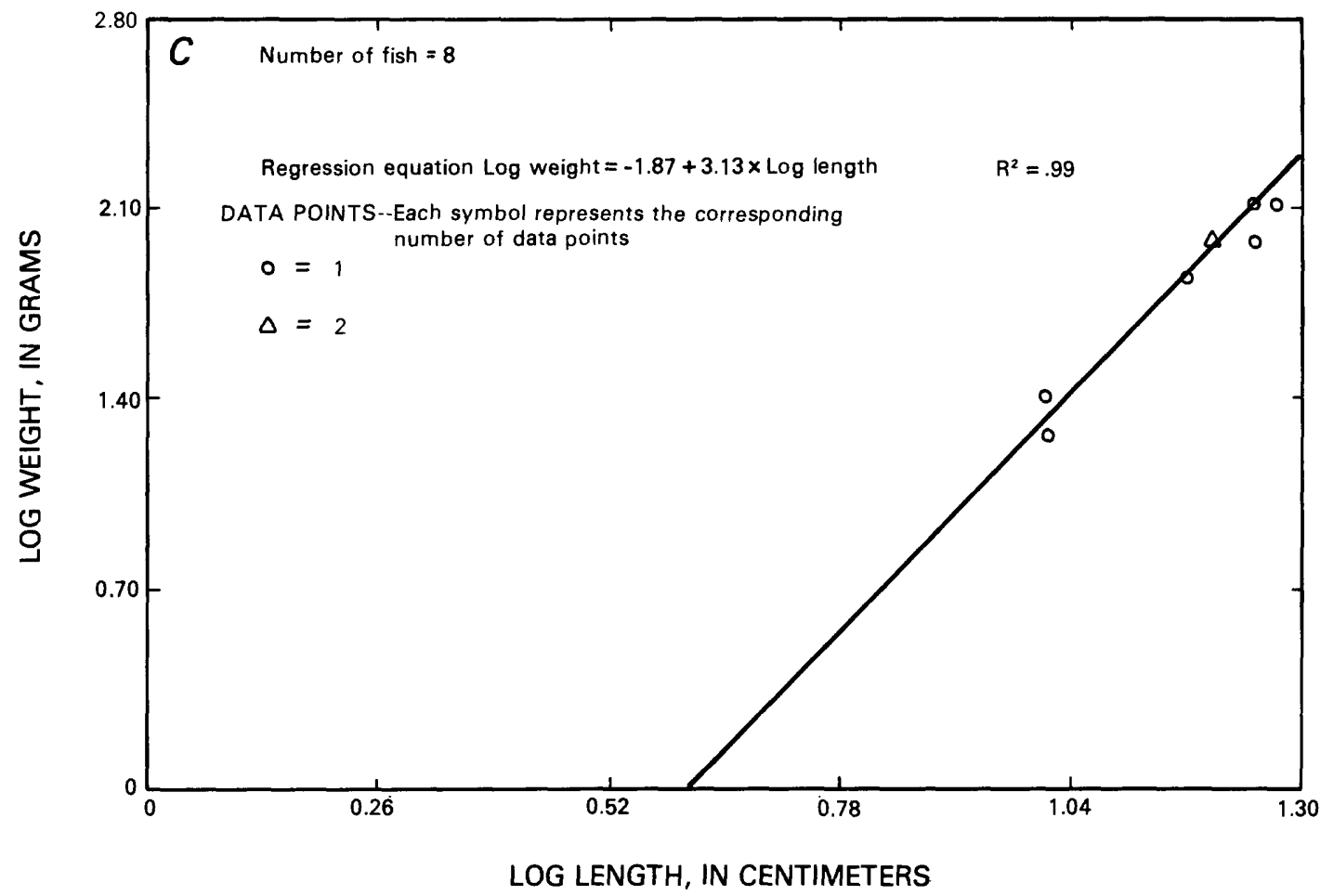

Figure 9.--Population characteristics of rock bass collected in August 1982. A. Relative abundance by length. B. Relative abundance by age. C. Relation of length to weight. 
Table 10.--Mean back-calculated lengths for black crappie collected in August 1982

[cm, centimeters ]

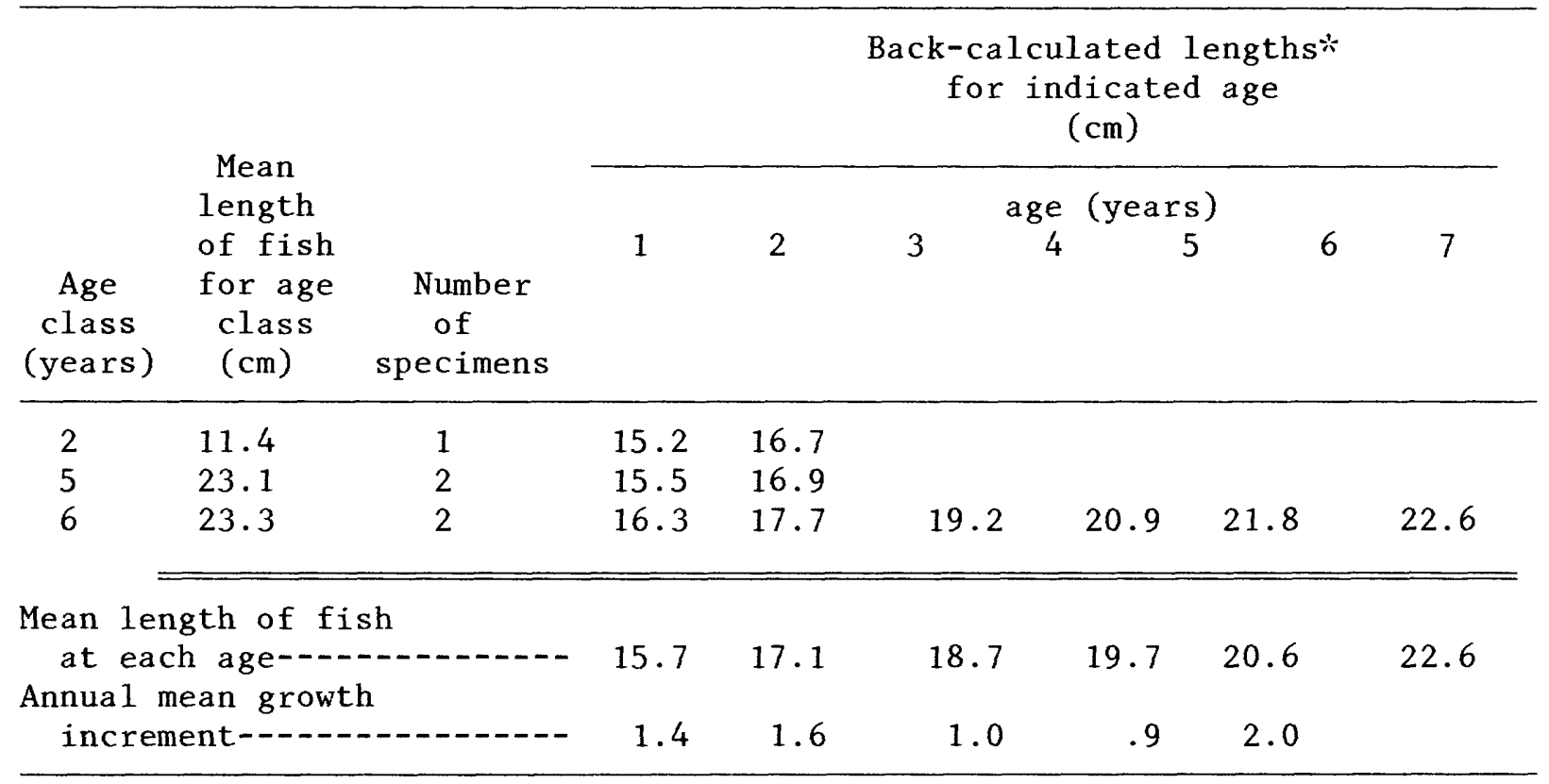

*Calculated average length of fish for each age class at a specific age in their life history. 


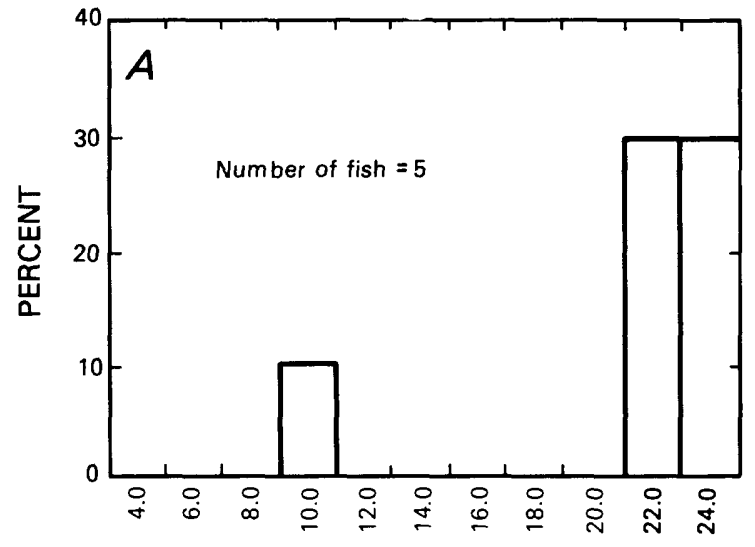

LENGTH AT MIDDLE OF INTERVAL, IN CENTIMETERS

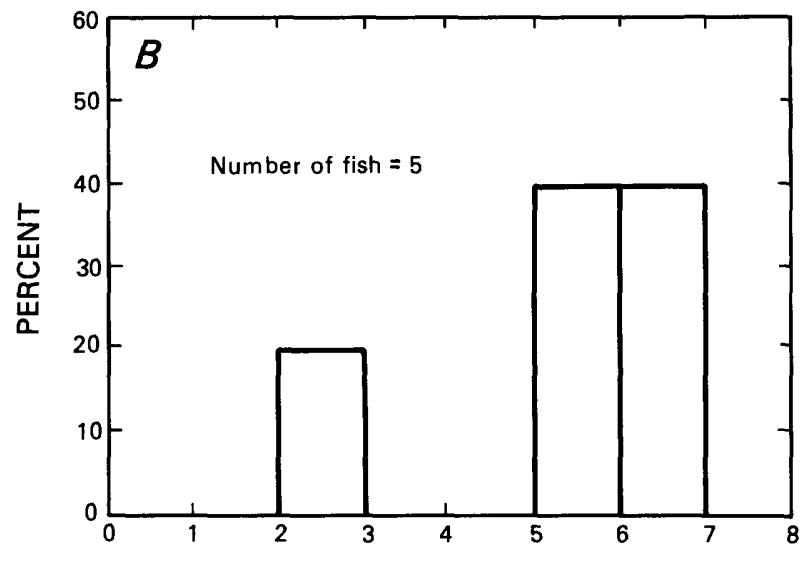

AGE, IN YEARS

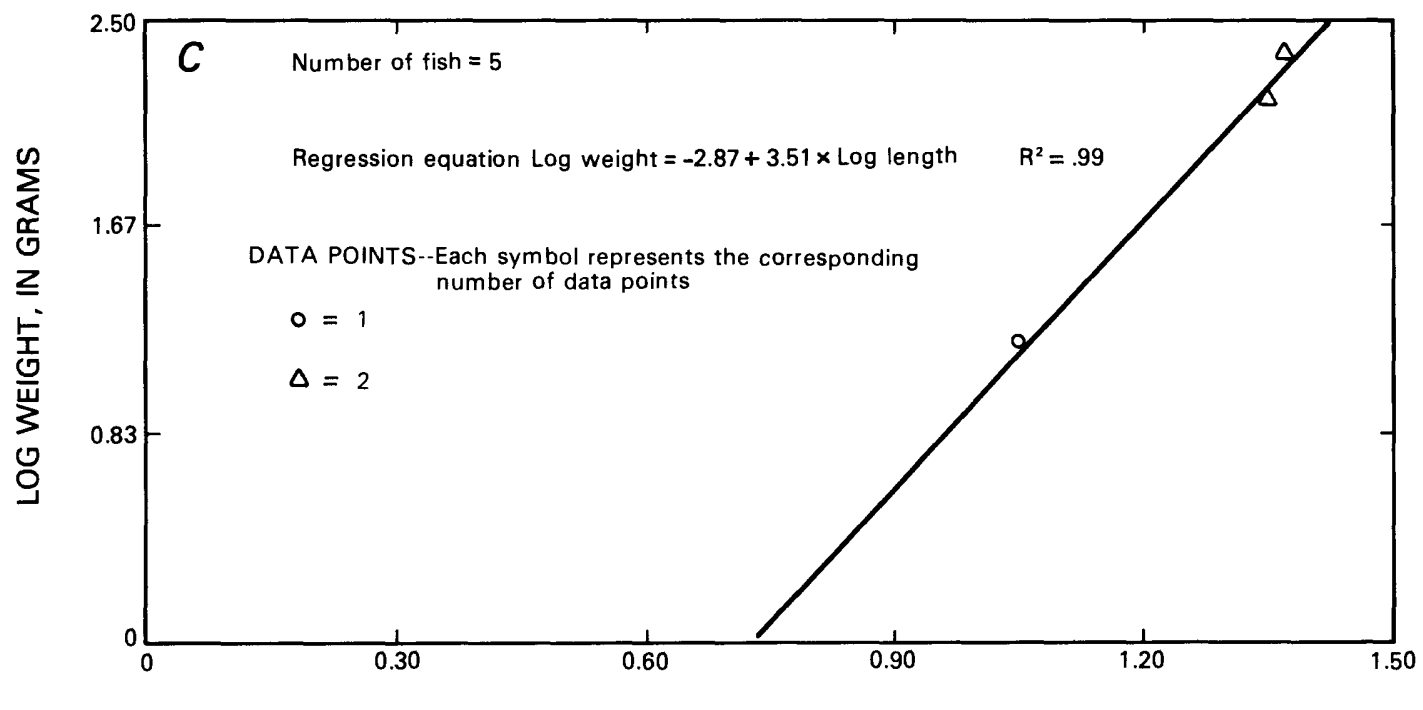

LOG LENGTH, IN CENTIMETERS

Figure 10.--Population characteristics of black crappie collected in August 1982. A. Relative abundance by length. B. Relative abundance by age. $C$. Relation of length to weight. 


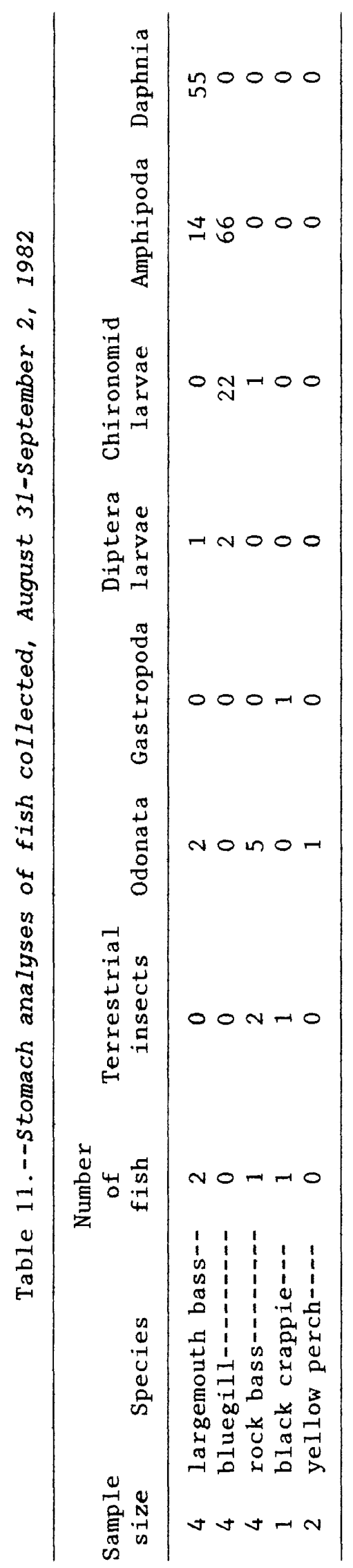




\section{REFERENCES CITED}

Bagenal, Timothy, ed., 1978, Methods for assessment of fish production in fresh waters, International Biological Programme Handbook Number 3, (3d ed.): Oxford, Blackwell Scientific Publications, 365 p.

Carlander, K.D., 1977, Handbook of freshwater fishery biology: Ames, Iowa State University Press, v. II, $431 \mathrm{p}$.

LaBaugh, J.W., Groschen, G.E., Winter, T.C., 1981, Limnologica1 and geochemical survey of Williams Lake, Hubbard County, Minnesota: U.S. Geological Survey Water-Resources Investigations 81-41, 38 p.

Ricker, W.E., 1975, Computation and interpretation of the biological statistics of fish populations: Ottawa, Fisheries Research Board of Canada, Bulletin 191, $382 \mathrm{p}$.

Siegel, D.I., and Winter, T.C., 1980, Hydrologic setting of Williams Lake, Hubbard County, Minnesota: U.S. Geological Survey Open-File Report $80-403,56$ p. 